UDC 347.135.224(477)

DOI https://doi.org/10.32782/2524-0374/2022-1/7

\title{
UNITY OF LOCAL AND SPIRITUAL POWER AS A STATE AND LEGAL DOCTRINE OF BYZANTIUM
}

\section{ЄДНАННЯ СВІТСЬКОЇ ТА ДУХОВНОЇ ВЛАДИ ЯК ДЕРЖАВНО-ПРАВОВА ДОКТРИНА ВІЗАНТІї}

\author{
Skovronskyy D.M., Candidate of Law, \\ Associate Professor at the Department of Theory of Law and Constitutionalism \\ Institute of Jurisprudence, Psychology and Innovative Education of Lviv Polytechnic National University
}

There are many different views on the influence and relationship of secular and spiritual power of Byzantium. Some researchers argue that ecclesiastical authority was virtually under the complete control of the secular, referring to the term "Caesaropapism", others argue in favor of the relative independence of spiritual authority. The Byzantines themselves tried to use the term "symphony" to denote the relationship between the two powers.

It is known that the next institution of state power after the emperor in Byzantium was the church. The importance of this institution was that it existed institutionally. Vasilevs, as Christian monarchs, could not arbitrarily reorganize or liquidate this institution, just as other members of the state administration could not do so. The church plays a huge role in the life of the empire. Relations between secular and ecclesiastical authorities differed significantly throughout the history of the empire. But most emperors enshrined as one of the state and legal doctrines the unity of secular and spiritual power. State and church organizations have never opposed each other. This may be a consequence of the traditional Byzantine interpretation of the church as a whole community of believers. The issues of spiritual guidance of people and the organization of management of everyday life of society here form an organic unity.

Byzantine political and legal doctrine distinguishes between the concept of state, sources of state power, the personality of the ruler and the institutions of public administration, the concept of the people stands out. For many centuries of Byzantine history, the succession of the Roman Empire was officially proclaimed. The central element of statehood is the institution of imperial power. The emperor acts as his personification. This institute combined the principles of a single monarchical and ancient Roman republican system.

This topic for study is occupied by questions of ideas of Byzantine thinkers about the origin of the state, which is largely a reflection of their ideas about its nature and purpose. The Byzantines tried to combine two rather incompatible theories of the origin of the state.

The main purpose of the exercise of state power was officially recognized as the achievement of "universal justice", which was embodied, first of all, in the legislative guarantees of "economy", social compromise. This circumstance was largely combined with the popularity of the doctrines of "social contract" and "organic" organization of the state.

In the spirit of the Christian tradition, recognizing that all authority is authority from God and that any state institution is his creation, which is a manifestation of his merciful attitude towards the human race, they nevertheless continued quite consistently throughout the history of the empire. to defend the ancient theories of the origin of the state, using, like many Western thinkers, the works of Plato, Aristotle, Polybius, Cicero and others. The "contractual" theory of the origin of the state was not a tribute to the tradition of ancient heritage, it continued to develop, finding its consolidation even in some legislative acts.

Theories of "contractual" origin of the state and the organic assimilation of socio-political organization, with one essential feature, were the main ideas of the political and legal system of society. The state is organized by man, but in this act the divine will, divine providence, was manifested. God, by expressing the will of the citizens, authorizes the power of a particular emperor.

In addition, the political system itself is similar to the divine organization - one God in heaven, one emperor on earth. The "treaty" imprisoned by the people embodies the divine will for a reasonable and sacred organization of human society. No man has the right to change the existing order of things, not even the emperor. The very thought of such a possibility is a grave sin. In the political and legal views of Byzantine, both secular and religious thinkers, it is traditional to refer to the experience of direct divine expression of will through the popular election contained in the Old Testament.

Key words: Byzantium, state, society, power, emperor, church, political and legal views, God, divine will.

Існує безліч різних думок про вплив і співвідношення світської та духовної влади Візантії. Одні дослідники відстоюють ідеї про те, що церковна влада перебувала практично під повним контролем світської, позначаючи це терміном «цезаропапізм», інші наводять аргументи на користь відносної самостійності духовної влади. Самі візантійці намагалися користуватися терміном «симфонія» для позначення співвідношення двох влад.

Відомо, що наступним після імператора інститутом державної влади у Візантії виступала церква. Важливість даної установи полягала в тому, що вона інституційно існувала. Василевси як християнські монархи не могли довільно реорганізувати або ліквідувати цю установу так само, як не могли цього зробити й інші ланки апарату державного управління. Церква відіграє величезну роль в житті імперії. Відносини установ світської та церковної влади значно різнилися протягом історії імперії, але більшість імператорів закріплювало як одну із державно-правових доктрин єднання світської та духовної влади. Державна і церковна організація ніколи не протиставлялися одна одній. Можливо, це є наслідком традиційного для Візантії широкого тлумачення церкви як всієї громади віруючих. Питання духовної настанови людей і організації управління повсякденним життям суспільства тут складають органічну єдність.

Візантійська політико-правова доктрина розрізняє поняття держави, джерела державної влади, особистості правителя і інститутів державного управління, окремо виділяється поняття народу. Протягом багатьох століть історії Візантії офіційно проголошувалася спадкоємність існування Римської імперії. Центральним елементом державності $є$ інститут імператорської влади. Імператор виступає як його уособлення. У цьому інституті поєднувалися принципи одноосібного монархічного і стародавнього римського республіканського ладу. Основною метою здійснення державної влади офріційно визнавалося досягнення «загальної справедливості», що знаходило своє втілення насамперед у законодавчих гарантіях досягнення «економії», соціального компромісу. Ця обставина багато в чому поєднувалася з популярністю доктрин «суспільного договору» і «органічної» організації держави.

Дану тему для вивчення займають питання уявлень візантійських мислителів щодо походження держави, що є багато в чому відображенням їх ідей про її природу і призначення. Візантійці намагалися поєднати дві досить несумісні теорії походження держави. У дусі християнської традиції, визнаючи, що будь-яка влада $є$ владою від Бога і будь-яка з державних установ є його творінням, що $є$ проявом його милосердного ставлення до людського роду, вони, тим не менш, досить послідовно впродовж усієї історії імперії продовжували відстоювати античні теорії походження держави, користуючись, як і багато західних мислителів, працями Платона, Аристотеля, Полібія, Цицерона та ін. «Договірна» теорія походження держави не була даниною традиції античної спадщини, вона продовжувала розвиватися, знаходячи своє закріплення навіть у деяких законодавчих актах. 
Теорії «договірного» походження держави й органічне уподібнення соціально-політичної організації, з однією суттєвою особливістю, були основними ідеями політико-правового устрою суспільства. Держава організована людиною, але в цьому акті проявилася божественна воля, божественне провидіння. Бог за допомогою волевиявлення громадян санкціонує владу конкретного імператора. Крім того, сам політичний лад подібний до божественної організації - один Бог на небі, один імператор на землі. Ув'язнений людьми «договір» втілює божественну волю про розумну і священну організації людського суспільства. Жодна людина не має права змінити існуючий порядок речей, навіть імператор. Сама думка про подібну можливість є тяжким гріхом. У політико-правових поглядах візантійських, як світських, так і релігійних мислителів традиційним є посилання на досвід безпосереднього божественного волевиявлення за допомогою народного обрання, що міститься у Старому Завіті.

Ключові слова: Візантія, держава, суспільство, влада, імператор, церква, політико-правові погляди, Бог, божественна воля.

The Byzantine Empire was characterized by an exceptionally high level of development of statehood in relation not only to the Middle Ages, but also to the modern world. It should be noted that many basic concepts of the nature of the state, the bearer of the state power, its sources did not have a normative definition. Byzantine political and legal concept accepts the doctrinal definitions of Roman thinkers, the fathers of the Christian church, the provisions of Scripture, the established practice and experience of their own people for the creation of the concept ofs the state power.

One of the features of Byzantine law is that the empire never adopted an act of the constitutional significance within one or another system of legally significant documents. Some researchers, such as V. Waldenberg, I. P. Medvedev and other scholars point to the existence of the so-called "unwritten constitution" - a set of very amorphous and mostly not recorded in law regulations and customs that determine the social and state structure of the empire [1, p. 29-43]. At the same time, the political and legal works and facts that have come down to us, known from various historical sources, speak of a well-established and effective system of the state power that allowed Byzantium to exist and develop over the millennium. The Code of Emperor Justinian I, the Eclogue, the Basilica, and numerous other codifications served rather as a kind of "civil" constitution of the state. The lack of clear legislation on the basic foundations of the state power does not indicate the dominance of the despotism of the emperors, a priori imperfect structure of the state apparatus. Most likely, this is an indicator of the high level of the development of the civil law consciousness of the Byzantines. Suffice it to mention modern Britain, where many provisions of the monarch's supreme power, organization and functioning of the political system, such as the right of absolute veto on laws and so on, are carried out according to centuries-old customs rather than the positive law.

Perhaps the Romans, in accordance with their political and legal views, considered it impossible to enshrine the fundamental issues of organization of the state power in the acts of the positive law, since the existing order is sacred and no one can formally define it because it is the prerogative of the divine will. The lack of a system of acts of "constitutional" significance necessitates the use of political practice in the study of the form of the Byzantine state and other important problems of the statehood development, which largely embodied legal customs, "current" legislation and doctrinal teachings of Byzantine thinkers.

According to the political and legal views of the Byzantines, their state continued to develop the Roman Empire. Roman law did not officially cease to operate within its borders Byzantium gives an example of a unique state in the medieval world. The Romans were an ethnic or tribal association. Initially, it was a civil-political community. Distinctive features of Byzantine legal consciousness were the ideas of the choice of Romania as a world empire, the paradoxical combination of ancient political and legal heritage with the Christian doctrine of the state and the institutions of medieval feudal society. In 330, Constantinople became the official capital The third canon of the Council of Nicaea in 381 established the doctrine of the emergence of the "New Rome" the Christian kingdom. But these views did not immediately dominate. For most late Roman thinkers, such as Ammianus
Marcellin, Libanov and others, the idea of "Eternal Rome" is characteristic. The assertion of Constantinople as the successor to the capital of the empire and the whole Christian world became the dominant doctrine only in the VI century. Such thinkers as Procopius, Agaphius and others have already seen themselves as citizens of the world Christian empire, the center of which was Constantinople - "New Rome" [2, p. 200-217].

Traditionally, the starting point of the new state is 395, the official division of the Roman Empire into East and West. It should be noted that the relations between the two empires cannot be considered completely interstate. The emperors of Constantinople rightly sanctioned the election of one or another Western emperor until the overthrow of the last of them - Romulus in 476. The only rulers of the universal state were the Byzantine Vasilevs, whose ideological and legal justification of power was supplemented by the provisions of the Christian religion, which identified the power of the one God over the world with the earthly power of "autocrat" over people. The concept of state power developed in Rome was preserved in its main features and received its further development in the Byzantine Empire. Quite amorphous political ideas about the state, whose power is embraced by the entire inhabited world, often found their real expression in legislation. For example, the laws of Emperor Justinian I officially had as their addressees "the whole globe" - in omnnen orben tenaum, universes hominibus - literally "all people", "all peoples", "all the land covered by Roman law" [1, p. 21].

The Christian world had replaced the Roman world. The fall of the empire under the pressure of the Crusaders and its transformation into a weak regional state in the XIII-XV centuries had little effect on political rhetoric. In 1370, Patriarch Philotheus called himself "the father of all Christians, wherever they lived. "The Basileus continued to consider themselves the heirs of the Roman Empire and, accordingly, asserted the superiority of their political status over other Christian monarchs. The political idea of the greatness of the empire in the official state and legal doctrine largely survived the real fall of the state. But never the less, in Byzantine political thought, the idea of the destruction of the imperial state and the birth of a new kingdom on its ruins, which does not have universal aspirations, which should basically rely on the ethnic Greek core. As an example we can cite the activities of the thinker of the XIV century George Plephon. He pointed to the need for the emperor's sole authority, but only within the framework of the Greek world of the cities of the Peloponnese, Thrace, etc. Byzantium is no longer the Roman Empire it is just one of many states in Europe and the Middle East" [3, p. 26].

The fundamental principles underlying Byzantine statehood were the logical development of Roman political and legal thought. The legal consciousness of Roman society developed an abstract concept of the state fully accepted by the legal consciousness of the Romans. It was reflected in a peculiar formula - "respublika". Literally it means "public thing" in the sense of "public, community affairs", which is largely identical to modern one - "state", "state power". The developed concept of sole monarchical power existed as well. The power of the ruler was defined as "Ministeum" serving the "common cause". The very concept of the state was based on the fact that it was a mechanism, a creation of the human mind, the people of Rome, designed to serve them and protect their interests. A division preserved by 
the legal consciousness of the Romans, the source, the bearer of state power and the exercise of power by state institutions or officials took place. The notions of the state as such, the people and the ruler, the ruler's personality and the institution of the head of state - the monarch - were divided. Due to the expansion of the empire, the impossibility of assimilation of many peoples the governing through a complex system of government, consisting of many elected institutions, largely duplicated each other and with weak vertical subordination was practically impossible. The necessity to centralize state power capable of responding most effectively and promptly to social processes was urgent.

The people were recognized as the source of state power. The people delegated its implementation to institutions, officials on a temporary or permanent basis. In 212, the rights of Roman citizenship were granted to the entire free population of the empire. By that time, the ethnic concept of "Roman" was completely dissolved in the state-political - "Roman citizen". Thus, the source of state power was a set of persons with the right of citizenship, united in the abstract concept of "Roman people", which serves as the name of some integrity that has absolute ideological value as the basis of the very existence of the state.

The institution of imperial power is central to the doctrine about the state. Byzantium is a state with a unique form government based on a combination of republican and monarchical principles. The emperor concentrates in his hands all the fullness of the state authorities. At the same time, his prerogatives are based on the act of the divine delegation of state power, which finds its declarative expression in elected by the army, the people and the senate. Conventionality of power is expressed in constant the possibility of electing a new emperor $[4$, p. 85-96]. The fact that it is in the person of the head of state, the emperor, is embodied basic ideas about the state do not indicate that degradation has occurred of this social institution. In contrast to Western Europe, where y "Barbaric" kingdoms formed in the western imperial provinces, there was a significant simplification of the Byzantine system of government the administrative system continued to evolve. The state itself "Barbaric" peoples, given the significant mixing of private principles and public law, began to be perceived as a kind of patrimony, private land tenure. For example, according to the Salic truth question succession was governed by the rules of inheritance of real estate property. In many ways, the apparatus of government was reduced to the very person of the king and his yard. In turn, Vasilevs was the personification of state power, and not its only embodiment. He represented in the eyes of the subjects all branched state mechanism, and at the same time was its most important institution. With the advent of Christianity as the state religion, in political and legal ideology there is a contradiction in the very assessment of the existence of statehood in general, which was unthinkable for Roman political and legal thought. In the Sacred scripture can be found as a justification for the existence of Rome as an incarnation world empire, a neutral attitude to the objective fact of reality, and denial of statehood. The teachings of the church fathers are also contradictory [5, p. 344]. For example, Clement of Rome, the third successor of the Apostle Peter, points out that it is necessary to obey both Christian leaders and earthly rulers. Justin the Martyr in the II century. AD urged Christians to pay taxes, recognize and to obey the authorities.

Meliton Sardskyi draws a fundamental parallel between the existence of the heavenly king Christ and the earthly emperor Augustus. But at the same time, Irenaeus of Lyons and Hippolytus of Rome, like many other thinkers, point to the diabolical nature of the Roman Empire, like ningit to the beasts of the prophet Daniel. The Roman Empire in herits the kingdom of Christ, but in fact gathers nations in the name of Satan. After the adoption of Christianity by Constantine Ias the state religion, the empire appears in the views of most religious and political thinkers as a gracious manifestation of the divine will.

Byzantium was a Christian state and its positive significance dominates the views of religious and secular Christian thinkers. The cornerstone of the doctrine of the universal Christian kingdom was laid by Eusebius of Caesarea (260-340). The views of this thinker became the main constructive feature of Byzantine political and legal thought and developed over the centuries. In his opinion, the Roman emperor is a likeness, an image of the king of heaven, the Logos-Christ [6, p. 10].

The relationship between God and the emperor is similar to the relationship between the Father and the Son. Efsevii considers the relationship between two divine persons as a kind of divine connection. The divine likeness of the earthly kingdom is proclaimed. The emperor, like Christ, has a sacred purity, consecrates his soul to God, then, as a shepherd, protects the souls of his subjects.

The head of state subordinates earthly enemies of the Christian faith. He is endowed with he knowledge of divine and human things. But the contradictions in the Christian political and legal doctrine regarding the essence of the empire of the Roman and Constantinople emperors persisted for centuries. For example, in the ninth century, Constantine the Philosopher pointed out that Christian Romania is not identical with pagan Rome, because it is essentially a different state: "Our kingdom is not Roman, but Christ's". The Byzantine Empire is the universal Christian kingdom foreseen and created by God. However, the official postulate of the continued existence of the Roman Empire and its political and legal heritage logically falls out of the political and legal doctrine.

The Byzantine emperor combined the features of three main rulers: he continued the traditions of the Roman emperor, despot of the Hellenistic monarchies and at the same time was a Christianking. Accordingly, there was an inevitable struggle for the establishment of republican and monarchical principles of state power, the balance of interests of the state and the individual, the responsibility of the head to the people.

The problem of the purpose and goals of the state's existence becomes extremely important. The emperor appears as a strict warrior, a just ruler who solemnly defends the laws of his state. The head of state must be simple in life and always ready to respond to his fellow citizens. A bad ruler is the one who violates the ancient laws and customs of the people. Many rulers possessed the features of a Hellenistic monarch, an absolute ruler, an "emperor god" surrounded by the eastern splendor of the court, and unaccountable control of a society. But the ideas that the head of state could dispose of his country arbitrarily, as if property, did not find public support. In the VII$\mathrm{XV}$ centuries the emperor embodies the idea, first of all, as a Christian monarch, to whom power is given by Godin the way of popular election, and he must be responsible for hi sactions in accordance with religious beliefs about the duty of a good Christian, God-appointed shepherd before his home land and fellow citizens. The value of the ruler' sactions is determined by the fact of keeping the divine commandments. But the personality of the monarch does not acquire sacred significance, his power is still conditional and associated with a real or formal act of popular recognition.

It is necessary to highlight the defining features of the doctrine of the exercise of state power. A unique feature of Byzantium in the medieval world was that in addition to the mandatory tasks of spreading religion, holy wars, defense of the fatherland stands out the main, "constitutional" principle of government activity. The goals of the state, the power of the emperor are to achieve universal justice. The concerns for the good of the people, justice, equality, and assertion of philanthropy are constantly mentioned in the acts of emperors. In the Tiberius's novella of 575, economy and philanthropy are declared as the main principles of law. It is pointed out that "justice" is the area subject to the law "to give to everyone 
equally and not to strive for anything else", "humanity" is the area to feel compassion and free from the difficulties of those who are in need. It is argued that the government should provide the subjects with everything they need and come to their aid. The desire for "economy", achieving social compromise is one of the principles of Byzantine law. Legislation and jurisprudence provide numerous examples of state action in the interests of the underprivileged to the detriment of the nobility [7, p. 122]. Perhaps this was due to the desire of the emperors to have maximum social support and prevent the emergence of strong hereditary nobility.

In political and legal doctrine, equality, as the embodiment of justice, had four main meanings: legal, natural, property and of equality before God. In the field of ideology, regulations as well as many thinkers in their works point to the fact, first of all of property inequality as a cause of violation of justice, disrespect for the law. In a speech of Justin II to Tiberius, the main idea was that power should not be an instrument in the hands of the upper classes, for it has an important social task - to promote the equal distribution of material goods among the social classes. But it should be noted that Byzantium was a medieval state in which there was an institution of slavery and the class gradation of the population. The purpose of the existence of the state is not to meet the needs of everybody, but to repay everyone the right that belongs even to him, which has been directly and repeatedly enshrined in law. It is largely a question of pursuing a policy not of "arithmetic" but of "geometric" equality. The "constitutional" principles of the goals of the imperial government in the most general terms were that the state guaranteed equal distribution of rights to all citizens. Within the framework of the provision in a rather flexible social structure, the citizen was guaranteed his rights. Elimination of property inequality was not a principle of state activity. Legislation is imbued with a spirit of respect for the institution of private property. This aspect should be primarily an act of the State and individuals' mercy, and the prevention of restrictions on the rights of the poor by the rich and the fair court of emperors. Rewards and punishments should be distributed according to the merits of each man.

\section{REFERENCES}

1. Медведев И.П. Правовая культура Византийской империи. Санкт-Петербург : Алетейя, 2001. 576 с.

2. Удальцова 3.В. Идейно-политическая борьба в ранней Византии. Москва : Наука, 1974. 352 с.

3. Общественно-политическая мысль Византии в 40-60-е гг. XIV в. Свердловск, 1986. 81 с.

4. Острогорський Г. Історія Візантії. Львів : Літопис, 2002. 608 с.

5. Історія Візантії. Вступ до візантивістики / за ред. С.Б. Сорочана і Л.В. Войтовича. Львів : Видавництво «Апріорі», 2011.880 с.

6. Харитонова Т.Є. Систематизація права у Візантійській імперії у першій половині VI ст. н.е. (систематизація Юстиніана) : автореф. дис. ... канд. юрид. наук. Одеса, 2003. 16 с.

7. Долинська М.С. До питання рецепції візантійських норм як передумови зародження нотаріального законодавства України. Вісник Національного університету «Львівська політехніка». Юридичні науки. 2014. № 801. C. 121-124. URL: http://nbuv.gov.ua/UJRN/ vnulpurn_2014_801_24. 